\title{
XIGUBOS, PANDEIROS E ATABAQUES: INSTRUMENTOS COMO MEIO DE ACESSO AO SOBRENATURAL NO BRASIL E EM MOÇAMBIQUE ${ }^{1}$
}

\author{
Artur Costa Lopes \\ Érico de Souza Brito \\ Clayton da Silva Guerreiro ${ }^{2}$
}

Resumo: Este artigo busca traçar conexôes que determinados instrumentos musicais executam entre o plano dos seres humanos e o plano do sagrado em distintos contextos religiosos. Serão analisados o xigubo nos cultos Zione de Moçambique e, no Brasil, o uso do pandeiro na igreja Assembleia de Deus, e do atabaque no candomblé por meio de etnografias feitas por um músico e dois antropólogos. Para tanto, adentramos em temas como permissóes de uso, posição dentro do rito, eletrificação e corporeidade, para demonstrar como tal conexão é implementada. O papel de mídia exercido pelos instrumentos musicais investigados demonstra que, mesmo em campos de pesquisa com pouca (ou nenhuma) relação entre si, o contato entre ambos os planos (humano e sobrenatural) tem na música produzida a corrente de contato que conecta os seres humanos ao sagrado.

Palavras-chave: etnomusicologia; pentecostalismo; Zione; candomblé.

1 Como citar: LOPES, Artur Costa; BRITO, Érico de Souza; GUERREIRO, Clayton da Silva. Xibugos, pandeiros e atabaques: instrumentos como meio de acesso ao sobrenatural no Brasil e em Moçambique. Debates do NER, Porto Alegre, ano 21, n. 40, p. 447-484, 2021.

2 Artur C. Lopes é doutorando em Música pela Universidade Federal do Rio de Janeiro e professor de música da prefeitura do Rio de Janeiro e de história pela Secretaria de Educação do Estado do Rio de Janeiro, Brasil. E-mail: lopes193745@gmail.com. ORCID: https://orcid.org/0000-0002-2445-6083. Érico de S. Brito é doutorando em Ciências Sociais pela Universidade Federal de São Paulo, Brasil. E-mail: ericosbrito@ gmail.com. ORCID: https://orcid.org/0000-0003-2145-635X. Clayton da S. Guerreiro é Doutorando em Ciências Sociais pela Universidade Estadual de Campinas, Brasil, com período sanduíche na Utrecht University, Holanda. E-mail: clayton.guerreiro@yahoo. com.br. ORCID: https://orcid.org/0000-0002-2227-9925.

Debates do NER, Porto Alegre, ANo 2I, N. 4O, P. 447-484, Ago./DeZ. 202 I 
XIGUBOS, PANDEIROS AND ATABAQUES: MUSICAL INSTRUMENTS AS MEANS OF ACCESS TO THE SUPERNATURAL IN BRAZIL AND MOZAMBIQUE

\begin{abstract}
This article seeks to trace connections that certain musical instruments perform between the plane of human beings and the plane of the sacred in different religious contexts. The xigubo will be analyzed in zione cults in Mozambique and, in Brazil, the use of the tambourine in the Assembly of God church, and the atabaque in Candomble through ethnographies made by a musician and two anthropologists. To do so, we went into topics such as permissions for use, position within the rite, electrification and embodiment, to demonstrate how such a connection is implemented. The media role played by the investigated musical instruments demonstrates that, even in research fields with little (or no) relationship to each other, the contact between both planes (human and supernatural) has in the music produced the current of contact that connects beings human to the sacred.
\end{abstract}

Keywords: ethnomusicology; pentecostalismo; Zione; candomblé.

\title{
INTRODUÇÃo
}

Este texto objetiva discutir o lugar de determinados instrumentos musicais em três contextos rituais, nomeadamente: Igrejas Zione em Maputo (Moçambique), uma Igreja Assembleia de Deus e um terreiro de Candomblé Ketu no Rio de Janeiro (Brasil). Nossa ideia é abordar esses três segmentos a partir da noção de periferia, conforme os escritos de Ginzburg (1986), que aponta para a valorização de fenômenos aparentemente marginais, como ritos de fertilidade ou de casos obscuros, protagonizados pelos pequenos e pelos rejeitados. Ao privilegiar estes segmentos excluídos, situados em zonas de clivagem, o autor problematiza a conjuntura periférica relacionando-a aos conflitos existentes entre distintas configuraçóes socioculturais.

Debatendo a relaçáo centro-periferia para além de binômios, Ginzburg revela que o entendimento do centro como produtor de cultura e da periferia como extensão, encontra-se na ordem tautológica, e amplia as dificuldades de análise ao invés de superá-las. Portanto, periferia, aqui, não é entendida apenas 
como um grupo que reproduz padróes de uma elite do centro e náo tem uma simples conotação geográfica, mas é vista dentro do contexto da circularidade cultural, que indica o poder de autoria dos atores sociais em diferentes circunstâncias, incluindo aqueles que são discriminados e subjugados.

Com base nesses três contextos periféricos, propomos uma abordagem que parta dos instrumentos musicais para a compreensão de processos sociais no interior dos enquadramentos religiosos supracitados. Supondo a importância da materialidade nessa investigação, nossa reflexão se aproxima da proposta de autores como Jeremy Stolow e Birgit Meyer. Como Stolow, supomos que "práticas e relaçóes corporais entre os atores humanos, lugares e forças não-humanas - natureza, espíritos ancestrais, santos, deuses" possibilitam interações que contribuem para a formação de comunidades religiosas, "forjando a sensibilidade de seus participantes" (2014, p. 153). Nesse sentido, concordamos com Meyer (2015) de que é preciso se perguntar como a "religião ocorre materialmente" e acreditamos que uma boa forma de realizar essa análise é focar na sonoridade produzida por instrumentos musicais, os quais envolvem corpos humanos e forças sobrenaturais, como deuses e espíritos.

Os instrumentos, por sua vez, não serão abordados como simples artefatos que compóem uma paisagem sonora (Schafer, 2011a) dentro de um ambiente polifônico (em diálogo com outros sons), mas como mídias poderosas capazes de transportar sujeitos do mundo natural para o sobrenatural, além de contribuir para a (re)modelagem de rituais, corpos e imaginários. Embora a categoria mídia esteja geralmente associada aos meios de comunicação, inclusive com a reivindicação de um campo exclusivo de estudos na antropologia (Ferreira, Travancas, 2014), aqui a noção de mídia é tomada em seu sentido mais amplo. Trata-se, nesse ponto, de refletir sobre coisas e corpos, isto é, "meios de transporte de conteúdos que conectam as pessoas umas com as outras e com o divino" (Meyer, 2015, p. 149), a fim de tornar o sobrenatural tangível. Tal perspectiva vai ao encontro do que também propóe Robert Orsi (2012, p. 147), para o qual o "invisível” torna-se "visível” através de mídias que podem ser negociadas, barganhadas, beijadas e tocadas. 
Em outros termos, a religião permite que o invisível se torne sensível, e é através de mídias materiais, como corpos e coisas, que o sobrenatural pode ser experimentado na realidade dos praticantes das religióes.

Neste artigo, abordaremos o uso do $x i g u b o^{3}$, uma espécie de tambor também chamado de batuque, que é bastante usado no acompanhamento de canções nos rituais Zione, em templos, praias e casas. Por Zione, referimo-nos às diferentes denominaçóes, entre tantas outras no continente africano, classificadas como African Independent Churches (AICs). As igrejas Zione têm origem na África do Sul e se caracterizam, de modo geral, pelo entrelaçamento de práticas e concepções cristãs, veterotestamentárias e aquelas consideradas "tradicionais", como as consultas aos espíritos dos antepassados (Comaroff, 1985; Cavallo, 2013). Apesar disso, há inúmeras divisōes internas entre os Zione, variando entre diferentes igrejas e pastores, visto que algumas dessas congregaçóes têm abandonado a "tradição" causa da influência de segmentos evangélicos estrangeiros (principalmente brasileiros), seja por meio de colaboração com missionários ou pela concorrência das igrejas Zione com outras igrejas, como as de origem portuguesa, nigerianas e brasileiras, tal como veremos ao longo do artigo.

Em momento posterior, contemplaremos o contexto de uma congregação da Assembleia de Deus com foco no uso do pandeiro, instrumento típico de rodas de samba e de capoeira, mas que foi adaptado e é bastante utilizado pelos(as) assembleianos(as) não apenas em cultos, mas em festas, oraçốes no

3 Para além do uso nos rituais religiosos, o xigubo é um termo usado para nomear uma dança que emula as práticas dos guerreiros do povo vanguni, sul de Moçambique, os quais dançavam em preparação à guerra e em comemoração pelas vitórias, ao som dos tambores e cançôes. Atualmente, há um esforço para a manutenção dessas práticas culturais, através do seu ensino para crianças e adolescentes que, em geral, fazem apresentaçóes em áreas turísticas da cidade de Maputo.

4 Trata-se de uma categoria êmica largamente utilizada em Moçambique para referir-se a inúmeras práticas, como os tratamentos da medicina tradicional, a possessão espiritual, o uso de determinados artefatos e rituais, como nascimento, casamento e funeral. Para análises sobre a categoria "tradição" em Moçambique, ver: Fry (2000), Honwana (2002) e Passador (2011). 
monte, e outros momentos que contemplam manifestaçóes musicais. Destaca-se que a Assembleia de Deus, embora pioneira no pentecostalismo no Brasil fundada em 1911, em Belém (PA) - transformou-se consideravelmente ao longo do tempo e pode ser considerada uma ramificação evangélica plural, dependendo de qual "linha" segue e como age sua liderança local.

Finalmente, será abordado o uso do atabaque, também conhecido como ilú, instrumento utilizado no ritual público do candomblé, conhecido como xirê, a partir do trabalho de campo feito em um terreiro de nação ketu. $\mathrm{O}$ candomblé, fenômeno religioso tipicamente brasileiro, tem origem nas manifestaçóes religiosas de algumas populações da África ocidental, mas sua forma de organização, na qual foram aglutinadas diversas divindades do panteão iorubá, foi estabelecida no Brasil, mais especificamente na Bahia. A este candomblé de origem iorubá, chamamos de candomblé ketu. É no xirê, momento em que os orixás vêm à terra para dançar e distribuir sua energia vital, o axé, que a música ocupa lugar central durante a cerimônia. Dentre os vários instrumentos utilizados para a produção acústica durante o xirê, optamos por focar nossa análise no atabaque, instrumento cuja presença durante o xirêe é indispensável, sendo um dos principais responsáveis pela conexão entre Orun (o plano dos orixás) e o Aiyê (o plano dos homens).

O que segue, portanto, é um esforço reflexivo realizado a seis mãos, que consiste, primeiramente, em identificar o lugar de cada instrumento nos rituais abordados, com especial atenção para discussôes entre adeptos(as) sobre as conexôes desses instrumentos com espíritos e humanos no mundo social. Para tanto, apresentaremos os dados etnográficos em separado, apresentando, ao final, uma reflexão sobre pontos transversais que emergiram do nosso esforço comparativo. 


\section{OS TOQUES DO XIBUGO}

Durante a noite, entre os becos do bairro da Mafalala ${ }^{5}$, o barulho dos rituais Zione se espalha pela escuridão e ajuda a identificar a congregação liderada pelo pastor João ${ }^{6}$, filho e neto de pastores e profetas e um interlocutor constante durante o trabalho de campo em Maputo, capital de Moçambique. Pessoas não ligadas às igrejas Zione disseram, por exemplo, que se sabe onde há um culto mazione (termo como os interlocutores costumam se referir aos Zione) através dos sons do batuque ${ }^{7}$ nos bairros. De dia, na praia da Costa do Sol, área nobre da cidade de Maputo, as ondas sonoras produzidas pelos Zione se confundem com as buzinas de carros, chapas (vans) e machimbombos (ônibus) que circulam na avenida marginal.

Em qualquer dos ambientes aludidos, músicas em changana $^{8}$, palmas, oraçóes dos profetas, gritos, gemidos, assobios produzidos por possessão espiritual e apitos são quase sempre acompanhados por um instrumento

5 O bairro histórico localizado no limite entre a parte central e os bairros adjacentes à cidade de Maputo, com uma população de aproximadamente 22 mil habitantes, sendo mais da metade muçulmanos e 80\% jovens. Conforme Valdemir Zamparoni (1998), no período do colonialismo português, o bairro era composto por um aglomerado de palhotas (casas feitas de palha e barro), em que morava uma populaçáo de negros que resistiam à violência colonial através de normas de convívio social, nascimentos, casamentos, funerais, festas e batuques que "obedeciam a uma lógica própria e eram realizadas com referentes cosmogônicos que não eram os do colonizador".

6 Usamos pseudônimos para preservar a identidade de todos(as) os(as) interlocutores, nos diferentes contextos.

7 Durante o colonialismo português, tanto no Brasil quanto em Moçambique, o termo era utilizado com uma conotação nativa e racializada. Em geral, os colonizadores associavam os batuques às festas dos africanos e seus descendentes, classificando suas músicas como mal executadas e de baixa qualidade. Atualmente, em Moçambique, o termo é usado pelos próprios crentes Zione para designar tanto o instrumento quanto o som produzido por eles.

8 Uma das cerca de 40 línguas faladas em Moçambique, predominante em Maputo Província e Maputo Cidade. 
musical bastante relevante naquele contexto, o xigubo ou batuque, formando uma espécie de "pequena enciclopédia sonora" durante os rituais. Por outro lado, em certas igrejas Zione já não se ouve o som do xigubo com tanta frequência e alguns instrumentos ficam empoeirados nos cantos. Em seu lugar, "pianos" (instrumentos conhecidos no Brasil como teclado eletrônico), caixas de som e microfones dão o tom ou amplificam os cânticos Zione. Nas diferentes igrejas brasileiras ${ }^{9}$ em Maputo, com destaque para a Igreja Universal do Reino de Deus (doravante IURD), o único instrumento usado para acompanhar as cançóes ou para servir como fundo musical para as orações também é o "piano". A princípio, o contexto polifônico das igrejas Zione, portanto, expóe modelos diferenciados, sobretudo sob a ótica de artefatos eletrificados e acústicos.

Grosso modo, o xigubo é um instrumento musical feito de lata e pele de animais, como a cabra, e produz toques graves que parecem reproduzir "as batidas do próprio coração" ${ }^{10}$, os quais podem ser facilmente aprendidos e executados por qualquer pessoa que esteja no culto. Apesar da importância do instrumento para o culto Zione, conforme descreveremos adiante, não é difícil adquiri-lo no calçadão da praia e em outros locais de Maputo, com o preço aproximado de 400 meticais (o equivalente a $\mathrm{R} \$ 25,10$, em maio de 2019), conforme informaçóes de um vendedor do instrumento, fiel da Assembleia de Deus, onde não se toca o xigubo durante os cultos.

A descrição acima, ainda que breve, permite-nos pensar em uma importante questão relacionada ao instrumento, qual seja, o lugar que o xigubo ocupa no culto Zione. De um lado, alguns interlocutores consideram que ele pode ser substituído por outros instrumentos musicais mais eficientes. De outro, há os que o tratam como um artefato eficaz e necessário para

9 Também destacam-se a Igreja Pentecostal Deus é Amor e Igreja Mundial do Poder de Deus, além de brasileiros ligados a missóes paraeclesiásticas, a outras denominaçóes, ou independentes que auxiliam projetos e igrejas locais.

${ }^{10}$ Referência a uma expressão utilizada no álbum Obaluyaè (1957), da Orquestra Afro-Brasileira. 
acessar o sobrenatural e agradar os espíritos dos antepassados. Entretanto, pode-se dizer que as evidências e percepçóes sobre o lugar de um instrumento musical no culto Zione desdobram-se em questóes mais estruturais, como as influências externas trazidas por missionários e pela mídia televisiva, em que se destacam os brasileiros; e a permanência de categorias coloniais, no bojo do dilema entre a busca por se mostrar "civilizado" e a eficácia de mídias associadas à "tradição", como pretendemos explicar adiante.

No caso da igreja da Mafalala, o uso do xigubo nos rituais é precedido por um período de preparação na parte da tarde, quando o instrumento é deixado secando ao sol, para amolecer o couro a fim de esticar a pele, com o objetivo de tornar o som mais agudo. À noite, entre corpos espremidos na pequena sala de estar que se torna templo, o xigubo embala cânticos e corpos, em um ritual no qual o silêncio é algo quase inexistente. Desde os primeiros minutos das reuniôes, já se ouvem cânticos e batuques, com os crentes alternando-se em versos musicais curtos e repetitivos nas línguas bantu do Sul de Moçambique, como changana e ronga. Após as cançôes iniciais, as leituras bíblicas e o momento de purificação do ambiente com incenso, fumaça, água e sal, os lapsos entre os diversos testemunhos individuais de cada crente são preenchidos pelos sons dos Zione.

Após a pregação de um texto bíblico, momento em que geralmente não há músicas, chega-se ao ponto alto do ritual, no qual os(as) fiéis executam a dança diliza. Trata-se, aqui, de uma dança em que participantes do rito bailam em roda, além de girarem sobre o eixo do próprio corpo, animados(das) por cânticos, palmas e batuques. Em geral, é nesse momento que o Espírito Santo ou os espíritos dos antepassados "saem" dos corpos das pessoas.

Cabe ressal tar que a utilização da expressão "sair" está longe de ser um recurso textual e retórico, mas busca seguir o que dizem os(as) interlocutores da pesquisa ${ }^{11}$. De acordo com Alcinda Honwana (2002, p. 54), trata-se de uma concepção metafórica que parte da ideia de que alguns "espíritos se encontram sempre no corpo da pessoa ou, pelo menos, que alguma força

${ }^{11}$ Todos e todas estarão com nomes falsos a fim de preservar o anonimato. 
espiritual potencial está dormente em cada pessoa até ser escolhida para desenvolver as suas potencialidades", sendo a manifestação social percebida durante as possessôes, momentos em que os espíritos saem dos corpos.

Com efeito, alguns(mas) interlocutores(as) disseram que os sons do xigubo são fundamentais para o culto Zione, porque permitem a conexão com o mundo espiritual, tanto para invocar os bons espíritos que auxiliam nos processos de cura quanto para fazer "sair" ou expulsar os mademonio, como são chamados os maus espíritos. Com essa mesma lógica, há tratamentos espirituais em que os profetas e seus assistentes assopram com apitos barulhentos nos ouvidos das pessoas possuídas, a fim de despertar os espíritos dormentes.

De certa maneira, a ideia de que os espíritos se manifestam através dos sons executados nos rituais também foi observada por Giulia Cavallo (2013), que descreveu uma situação no culto Zione da seguinte maneira:

Durante o culto, uma menina nova começou a ter um ataque. $\mathrm{O}$ espírito, o mademonio, manifestou-se depois dos batuques terem começado a marcar um ritmo. A crise foi forte, e logo depois da jovem manifestar o ataque, a pastora fê-la ajoelhar e começou o ritual para tirar, ou pelo menos acalmar, o espírito agitado. (Cavallo, 2013, p. 233)

Aqui, é preciso sinalizar que o som do xigubo afeta diretamente os corpos e os espíritos dos que recebem e dos que oferecem tratamentos espirituais. Como na análise de Cavallo (2013), durante os cânticos, danças, oraçóes e sons do batuque, há mademonio que se faz presente através de gritos, soluços, olhos revirados, balanços do tronco, quedas, dores e desmaios. Em geral, os espíritos se manifestam revoltados (Fry, 2000), exigindo coisas materiais, reivindicando atenção e sinalizando algum problema espiritual. Ao mesmo tempo, é nessa hora que os bons espíritos, chamados de mimoia (anjos) ou deuses, podem "sair" dos corpos dos profetas, capacitando-os a lidar com os demais espíritos, seja expulsando-os, negociando com eles ou instruindo as pessoas "tratadas" a fazerem rituais específicos para agradar aos espíritos ou combater a feitiçaria. 
É bem verdade que esse não é o único momento de manifestação dos espíritos, os quais podem aparecer nas escolas, nas casas, na rua, em outras igrejas ou no cemitério, como foi possível notar durante uma cerimônia de seis meses de morte de um profeta Zione, que também exercia o ofício de nyanga (curandeiro ou médico tradicional). Todavia, nos cultos Zione pesquisados em Maputo, os principais momentos de manifestaçóes espirituais se davam durante a diliza, ao som dos toques dos batuques.

Como afirmamos acima, algumas pessoas que fizeram parte da pesquisa disseram que os cultos poderiam ocorrer perfeitamente sem o xigubo, enquanto outras consideravam o instrumento insubstituível. Em uma discussão na praia com outros profetas e pastores, alguns deles afirmavam que o xigubo é dispensável e pode ser substituído por outros instrumentos, sendo o principal deles o "piano" (teclado). Por outro lado, entre os que defenderam a continuidade do xigubo no culto Zione, o Pastor João argumentou que uma das vantagens do instrumento é o baixo custo e a facilidade de execução musical. Ou seja, o preço relativamente barato e a não exigência de um aprendizado ou consagraçáo especial - embora as quartas-feiras devam ser dedicadas à consagração dos profetas por meio do jejum e da abstinência sexual - torna o instrumento mais acessível para a comunidade dos(as) fiéis. De acordo com ele, o batuque não somente é barato e mais fácil de tocar, como é parte da "natureza" Zione. Em outra conversa, Joáo declarou que há alguns espíritos em seu corpo que só podem "sair" ao som do xigubo: "quando você toca batuque, aqueles espíritos antigos saem. Com 'piano', os meus não podem sair. Os meus querem aquelas coisas antigas".

Em outras palavras, os "espíritos de João"12 exigem uma mídia que realize uma conexáo entre esse mundo e o sobrenatural. Nesse sentido, argumentamos mais uma vez em favor de uma perspectiva teórica que, conforme Jeremy Stolow, considera inexistente qualquer prática religiosa

12 Durante nossas conversas, o pastor/profeta costumava referir-se aos antepassados que o ajudam nos rituais como "meus espíritos". 
sem a mediação de coisas materiais, visto que a religião é "inerente e necessariamente entrelaçada aos objetos, técnicas e instrumentos do mundo material no seio do qual os atores e as ações religiosas são incorporados" e que tornam possíveis “ideias, experiências, práticas e modos de associação religiosos” (Stolow, 2014, p. 152).

Se o batuque é uma mídia essencial para o ator supracitado, há pastores e profetas Zione que estáo cada vez mais convictos de que se trata de um instrumento dispensável para seus cultos. De modo geral, esse argumento passa pela noção de que o xigubo pode ser substituído por outros instrumentos, sendo o principal deles o "piano" (teclado). Nesta perspectiva, o artefato está diretamente associado com a "tradição", em oposição ao "piano" e a uma aparelhagem eletrônica, estas vistas pelos interlocutores como símbolos de "modernidade" ou "civilização".

Durante a discussão do pastor Joáo com seus colegas na praia, alguns deles ressaltaram que uma das vantagens do "piano" é a possibilidade de produzir diferentes tipos de som, como de bateria, guitarra, contrabaixo ou variados instrumentos de sopro. Sobre isso, o bispo José, da Igreja Itzambulo Espírito Santo Zione, afirmou que teria interesse em abolir o batuque dos seus cultos, chamando esse processo de "limpeza" (acrescentamos: acústica e da "tradição") e ressaltando que o "piano" também poderia simular sons de batuque:

Sabe, anteriormente, aquilo era útil. Por exemplo, agora, o senhor é missionário, chega aqui, apanha a gente batendo palma: "Oh, isso é demônio". Vẫo chamar assim, que é demônio. Sem pensar que nós também queremos coisas boas. Ainda batemos batuques. Não é tradiçáo, é falta de dinheiro. Não temos condiçóes. Se temos condiçóes, não vamos ainda bater batuque. [...] Porque vocês lá não têm aquele tipo. Agora, quando chega aqui na África... Por exemplo, no meu caso, bater o batuque não é tradição. É por falta do melhor. Se a gente apanha melhor, vamos deixar o batuque atrás, trocamos para frente. Falar também do micro [fone]. Nós não temos aqui. A gente também quer coisas boas.

Junto com a tentativa de se desvencilhar da "tradição", o bispo declarou ainda que o batuque continuava sendo necessário para embalar os cânticos e 
danças, enquanto sua filha Alice, assídua frequentadora dos rituais na praia e bastante próxima de profetas que trabalham com as "coisas da tradição", incluindo a possessão de espíritos dos antepassados, negou que o batuque fosse um instrumento do "demônio", ressaltando que no livro bíblico de Salmos há a instrução para agradecer a Deus por meio de "vários instrumentos". De acordo com ela, "aquilo que nós acharmos que, se a gente tocar, vai fazer barulho, dá para a gente agradecer a Deus".

Da fala do bispo José, dois aspectos foram perceptíveis: a concepçáo de que a substituição do batuque pelo "piano" indicaria uma espécie de desenvolvimento material e a rejeição da "tradição" consonante à influência dos missionários estrangeiros. Um culto dominical na igreja do bispo José, justamente quando as "mamanas" (senhoras da igreja) tinham conseguido comprar uma caixa de som e dois microfones sem fio para a congregaçáo, após um ano de arrecadação, ilustra ambos os aspectos. A empolgaçáo era visível e, embora o som emitido pelos aparelhos eletrônicos não fosse dos melhores, todos demonstraram muita satisfação com a ideia de terem adquirido artefatos que o bispo José considerava símbolos de desenvolvimento financeiro e espiritual.

A cena descrita tem relação com o que Cavallo (2013) presenciou em uma igreja Zione, em Maputo. De acordo com ela, por influência de estrangeiros, nomeadamente missionários brasileiros, os(as) jovens daquela igreja estavam aprendendo a tocar diversos instrumentos musicais de sopro ou de corda, realizando o que o bispo da referida igreja classificou como "reforma dos batuques", o que evidenciaria um "desejo de ser moderno". $\mathrm{Na}$ esteira desse argumento, também é possível afirmar que se trata de um desejo de mimetizar as igrejas de origem brasileira, representadas pelos missionários que trabalham em Maputo, visto que há todo um imaginário social construído acerca do Brasil em Moçambique, através da mídia e dos missionários que apresentam o primeiro como um paradigma de desenvolvimento para o segundo.

No caso do bispo José, a proposta de "limpeza" das coisas também parece estar diretamente ligada à sua relação com missionários e pastores brasileiros. 
Ocorre que o governo moçambicano só permite a abertura de novas igrejas mediante a apresentação de diplomas teológicos e esses cursos geralmente são oferecidos por igrejas como a Assembleia de Deus, em que alguns dos professores são brasileiros ou têm contato com missionários brasileiros. $\mathrm{O}$ bispo José estudou em uma dessas igrejas e ouviu algumas instruçóes do diretor do seminário em relação aos rituais e ao funcionamento de sua igreja. Apesar de ter retirado determinados objetos rituais, como velas, batas e cruzes, o bispo conta que foi orientado pelo diretor a não deixar de usar o nome Zione em sua igreja, mas permanecer como tal e agir como um "embaixador" dos evangélicos entre os Zione, modificando paulatinamente suas práticas e rituais, o que o faz cada vez mais próximo dos evangélicos e distante dos Zione, diferente de sua filha, a quem ele classifica como a mais mazione da família.

Para finalizar, ressaltamos que alguns interlocutores citaram a IURD como exemplo de uma igreja em que mostra que o "piano" pode substituir plenamente o batuque. Em Maputo, os templos mais imponentes, construídos ou reformados recentemente, pertencem à IURD. O templo-sede, denominado Cenáculo da Fé, chama a atençáo pelo tamanho e pelo uso da tecnologia. Espalhadas pelo templo, no altar e no teto da igreja, as potentes caixas de som permitem ouvir com nitidez as vozes dos pastores e dos(das) fiéis entrevistados(das) ou exorcizados(das), após o contato com seres sobrenaturais.

O ritual segue um padrão internacional da IURD, com as músicas (quase sempre na língua portuguesa) sendo cantadas com o acompanhamento de um tecladista. Durante os exorcismos, as vozes dos presentes são silenciadas, exceto a do bispo ou pastor. Como Lívia Reis Santos (2018, p. 20) descreveu, geralmente há um aumento gradual do tom de voz dos bispos e pastores, alternando-se gritos e ordens aos espíritos da "tradição", chamados por eles de demônios, enquanto o tecladista executa uma "música de suspense", criando um "clima apropriado" para as manifestaçóes e posteriores expulsôes dos demônios. Tida por alguns(mas) interlocutores(ras) como uma igreja de destaque, tanto pela imponência material e domínio dos meios de 
comunicação quanto pela sua oposição à "tradição", a IURD também foi classificada por eles e elas como uma igreja Zione, porém civilizada, uma espécie de modelo a ser seguido, no que concerne ao uso da aparelhagem de som e do "piano".

Assim, se o xigubo é fundamental para os Zione, o "piano" iurdiano também contribui para criar sensaçóes e produzir um clima propício para manifestaçóes espirituais. Em todos os casos acima, os instrumentos parecem ser mídias capazes de produzir sensaçóes espirituais. Resta saber quais espíritos podem "sair" através do xigubo e quais podem se manifestar por meio do "piano".

\section{O PANDEIRO E O PENTECOSTALISMO}

Quinta-feira é dia de culto em uma igreja Assembleia de Deus na zona urbana de Xerém, distrito de Duque de Caxias (Rio de Janeiro). O ritual ocorre em um templo que se assemelha a uma garagem e está localizado em uma área de pouco tráfego, o que faz com que a região seja relativamente silenciosa no período noturno. Externamente, é possível escutar o som de algumas pessoas e carros transitando, além de latidos de cães.

Por volta das $19 \mathrm{hs}$, chegam algumas pessoas e, apesar da incerteza da presença do "rapaz que toca pandeiro", sabe-se que sempre haverá alguém para executar o instrumento. A acústica do templo é composta por um corinho ${ }^{13}$ semelhante a um bolero, e por crentes que chegam, ajoelham-se e oram em voz alta. Outros fiéis ligam o celular e deixam tocar algum louvor, enquanto algumas senhoras conversam e assistem vídeos no celular. Ainda nesse momento inicial de espera, o responsável por ministrar o culto desliga a música e testa o som com as palavras "Aleluia" e "Espírito Santo", enquanto um irmão ${ }^{14}$, ao fundo, está com o celular tocando uma música.

13 Para Cunha (2007), o Brasil tem ligação direta com composições oriundas de organizaçóes evangélicas paraeclesiásticas a partir da década de 1950, que buscavam criar um repertório com características da música popular brasileira através de instrumentos, linguagem e gêneros musicais.

${ }^{14}$ Maneira como muitos denominam seus próximos neste ambiente. 
Em certo sentido, as cenas descritas mostram semelhanças com a dinâmica de outras igrejas da mesma regiâo. ${ }^{15}$ As conversas com interlocutores(as) e as visitas ao campo indicaram que este artefato sonoro pode ser considerado um elemento presente no universo pentecostal, pois seu uso é recorrente, sobretudo em pequenas congregaçóes ${ }^{16}$ de Assembleias de Deus e em diversas igrejas independentes no cenário da periferia. Na igreja em questão, este instrumento costumava ser o único a ser tocado durante os cultos semanais. Em contrapartida, aos domingos, quando havia mais pessoas na igreja, outros eram adicionados, considerados pela membresia mais apropriados a grupos musicais, cantores e aos cânticos congregacionais.

$\mathrm{Na}$ maioria das vezes, alguma pessoa tocava pandeiro não como leigo(a), mas como alguém que conhece os códigos interpretativos do contexto em que está inserido(a). Há sempre um(a) instrumentista que sabe as convençóes dos hinos cantados pelos(as) membros(as). Quem se propóe a tocar geralmente tem conhecimentos prévios a respeito de como conduzir uma música, com propriedade sobre a linguagem do instrumento. Muitos(as) aprendem através da oralidade, em especial relacionada à "vivência cúltica" ${ }^{17}$. Muitos(as) interlocutores(as), ao responderem como aprendiam o pandeiro, diziam frases do tipo "eu sempre fiquei olhando, prestando atenção", "desde criança observo e

${ }^{15}$ Vale mencionar que a motivação para essa pesquisa surgiu pela atuação do pesquisador como professor de música em escolas da educação básica no Rio de Janeiro. Dentro do ambiente educacional, quando apresentava o pandeiro aos(as) alunos(as), normalmente executava diversos gêneros musicais. Quando tocava um baião, ou um gênero similar e pedia para os(as) estudantes adivinharem qual era o ritmo, imediatamente gritavam: "ritmo de igreja".

${ }^{16} \mathrm{Na}$ complexa estrutura hierárquica entre templos das Assembleias de Deus de um determinado ministério, pode-se afirmar, grosso modo, que há uma divisão entre a igreja-sede ou matriz e as congregaçóes, sendo estas submetidas àquela. Desse modo, a Assembleia de Deus, é composta por vários ministérios e várias convençóes, além de igrejas independentes que não possuem convençôes.

17 Aprendizado através da experiência em contextos religiosos, sobretudo em rituais ao longo da vida. Este pode ser externalizado através do que Bourdieu (2009) denomina habitus, em que códigos específicos podem ser visualizados.

Debates do NER, Porto Alegre, ANo 2I, N. 4O, P. 447-484, Ago./DeZ. 202 I 
fico de orelha em pé", "olhava como o pastor tocava e ficava ouvindo os hinos em casa e tentando acompanhar". Deste modo, "ouve-se o que se aprende a ouvir" (Menezes Bastos, 2013, p. 4), sobretudo na infância.

Dentro destes coletivos religiosos de Xerém a música pode funcionar como linguagem unificadora, mas também pode gerar conflitos com outros segmentos evangélicos e diversas formas de religiosidades afro-brasileiras. Aqui, nos referimos ao fato de que, nessas igrejas, é comum a execução de músicas que as discriminam abertamente ("pisa na farofa, chuta esse alguidar"), porém, ao mesmo tempo, os(as) próprios(as) fiéis dessas igrejas são acusados(as) de reproduzirem movimentos corporais das religióes que criticam, fazendo com que sejam acusados(as), através do uso de categorias nativas depreciativas, como "macumba pentecostal" ou "reteté" (Guerreiro, 2016; Pereira, 2019).

Tal como ocorre com o uso do xigubo, verificamos que, além de familiar à paisagem sonora da regiáo, o pandeiro é visto por muitos segmentos evangélicos com certo preconceito - em especial por igrejas náo pentecostais, pois, para algumas alas evangélicas, o instrumento é considerado um símbolo de atraso ou "de velho", mesmo com grande número de jovens participando. Logo, em concordância com Ginzburg (1986), o que pode ser considerado atraso também pode ser uma açáo coerente por parte de quem atua nessas experiências periféricas. Mesmo assim, musicistas evangélicos(as) normalmente emitem opinióes assertivas a respeito deste instrumento - "são típicos de igrejas pentecostais", "principalmente as que estão começando", "sempre acompanham os corinhos" -, seja pelo seu "toque empolgante", ou por ser um dos principais instrumentos que caracteriza o espírito pentecostal do fogo regido pelo Espírito Santo, como observado nos relatos de Adriano Pimentel e Felipe Sales:

Ele é uma opção mais barata. Eles acabam conseguindo resolver essa questão de deixar o culto mais animado, por causa do pandeiro, por causa do ritmo. ${ }^{18}$

${ }^{18}$ Pimentel, informaçấo verbal. Junho de 2017. 
O pandeiro, assim como outros instrumentos, harmoniza a música que está sendo tocada. Em algumas igrejas, o pandeiro é essencial. ${ }^{19}$

Em todas as igrejas pesquisadas os pandeiros tinham pele de nylon. ${ }^{20}$ Esta escolha está pautada em duas suposiçóes: baixo custo para aquisição e alto volume de propagação. Além disso, observamos que a maioria das músicas executadas durante a etnografia através do dueto voz e pandeiro podem ser categorizadas por derivaçóes de forró, samba e bolero. Notamos que em muitas conjunturas semelhantes a voz é acompanhada somente pelo violáo ou guitarra, porém, no caso dessa igreja, o instrumento acompanhador, sobretudo em ritos semanais, foi apenas o pandeiro.

Em outras situaçôes, pode haver mais de um pandeiro sendo executado simultaneamente, bem como acompanhando um playback (Lopes, 2016). Observamos, no entanto, que ele atua em uma posição dúbia, julgado "titular e reserva”, já que em algumas igrejas estão presentes apenas em cultos semanais ou em reuniōes nas casas, tal como ocorre no contexto Zione abordado anteriormente. Quando o culto é maior ele até pode ser utilizado, mas não recebe a mesma atenção que outros instrumentos da banda, sendo considerado algo que pode atrapalhar o conjunto. Neste caso, podemos supor que esses eventos não estão de acordo com a sensibilidade produzida pelos pandeiros, sensibilidade essa que requer, segundo o campo, características específicas, como um número pequeno de pessoas e informalidade acústico-ritual, ${ }^{21}$ por exemplo. Esta última situação pode causar alguns conflitos, principalmente se o conjunto musical for de fora (visitante), como destaca Pimentel:

O único problema é o seguinte: você pode ir lá com sua banda na igreja, tudo ensaiado (...) e você apresenta o louvor, adoraçáo, tudo, tudo tranquilo. Mas se tiver um irmãozinho com o pandeiro na mão, ele vai querer tocar com você. Mas no resto o pandeiro ajuda mesmo. ${ }^{22}$

${ }^{19}$ Sales, informação verbal. Maio de 2014.

${ }^{20}$ A outra opção é o couro, porém, além de ser mais caro, seu volume é mais baixo.

${ }^{21}$ Refiro-me a rituais que usam músicas não programadas anteriormente, fato que, durante a pesquisa, não foi empecilho para pandeiristas.

22 Pimentel. Informação verbal, 14 de junho de 2017. 
Embora este músico considere a atuação do pandeiro um problema, nesta situação, ele ressalta que o instrumento é fundamental para o funcionamento de igrejas menores, na qual é dispensável a utilizaçáo de outros, presentes em grande parte do cristianismo brasileiro atual, como o violáo ou o teclado. Esta percepção integra conflitos geracionais exibidos anteriormente também em Moçambique, com relação ao "piano" entre os Zione. Nesse sentido, o desejo do desenvolvimento material pode se articular não apenas com condiçôes de classe, mas com aspiraçốes a um novo lugar simbólico. Assim, adquirir instrumentos da moda, aparelhagem sonora "de ponta", ou mesmo uma nova estética para o espaço, pode ajudar a atrair um público maior, sobretudo jovens, já que a igreja torna-se mais "moderna", garantindo, também, a simpatia das novas geraçóes.

A construção de divergências a respeito da utilização do pandeiro o molda, pelo menos no recorte espacial da pesquisa, num elemento de identidade do pentecostalismo de periferia ${ }^{23}$ por pessoas de fora, que podem reconhecer alguns tipos de toque, ou por evangélicos que (positiva ou negativamente) consideram esse instrumento uma característica desse grupo. Desse modo, o resultado sonoro do uso do pandeiro e a em(anti)patia que este instrumento recebeu dos(das) fiéis pode ser fruto da capacidade de sociedades humanas de transformar o mundo sensível através de objetos manufaturados.

Ao mesmo tempo em que a prática dos(das) pandeiristas na igreja gera status social, também coloca-os(as) em uma posição inferior a outros(as) musicistas. Sobre este assunto, ainda vale mencionar que, nas igrejas observadas, muitos(as) pandeiristas náo tocavam outros instrumentos, e quando estavam aprendendo, ou quando havia possibilidade de troca, o pandeiro era deixado de lado. Para Pimentel, o pandeiro se basta e consegue agradar a maioria, já que dinamiza as músicas entoadas durante o ritual.

${ }^{23}$ Usamos esse termo como desdobramento da ideia de periferia apresentada na introdução. Nota-se que há pesquisas que investigam contextos semelhantes, com foco na música, como as de Pereira (2019), Guerreiro (2016) e Albuquerque Junior (2014). 
Pode ser o ritmo que for, que está lá o pandeiro. Pode ser música suave, rápido, lento [sic], o ritmo que for, que o pandeiro está lá. Não precisa do violão, não precisa do teclado, nenhum instrumento melódico. E dá certo cara, é uma coisa incrível que dá certo. Só com o pandeiro.

Com relação ao contexto musical do roteiro do culto em que o pandeiro se encontra mais presente a variação é grande. Em ordem decrescente de utilizaçáo encontramos o seguinte panorama: 1 - há igrejas que raramente utilizam playback ou outro instrumento além do pandeiro; 2 - outras limitam sua execuçáo apenas aos corinhos e; 3 - em menor escala, às músicas dos hinários.

Um pastor de outra Assembleia de Deus, a respeito do preconceito que as igrejas pentecostais menores sofrem com relaçáo a outros segmentos evangélicos, relatou que o que mais afeta este tipo de relação é a disparidade econômica entre muitas realidades, que se reflete na aquisição de palcos, luzes, grandes equipamentos sonoros, salóes imensos e variedade instrumental, que necessitam de altos investimentos. Considerando que a igreja não possui recursos para a aquisição de outros instrumentos (lá havia uma pandeirola, um tantan e um pandeiro), o pastor afirmou que se não há dinheiro para comprar outro, usa-se "o que tem à máo". Para ele, "o importante é louvar ao senhor com alegria". "Se não temos nada, podemos pegar aquilo dali (apontando para a lixeira de metal) e transformar num instrumento, podemos batucar e ficará muito bom”.

Ainda que a falta de recursos econômicos fosse visível nestas igrejas menores, em muitos casos notamos que isto era um passo a ser superado a partir da fé e perseverança do líder e dos(as) membros(as). O mesmo líder religioso ainda relatou que ficou orando sozinho durante pouco mais de dois anos, até algum crente começar a participar da igreja, e que, atualmente, ele vê os frutos plantados serem colhidos. Neste sentido, destacamos que a opçáo por um instrumento que faça parte de uma paisagem sonora compartilhada, assim como de baixo custo, é uma estratégia da Assembleia de Deus, mas também dos Zione no uso do xigubo, como mencionado no tópico anterior. 
O pandeiro foi visto sendo utilizado tanto por homens quanto por mulheres e a maneira de tocar não variava muito com relação ao gênero. Normalmente executado com as duas mãos, em constante movimento e sempre tocado com bastante força. Em diversos momentos havia pausas rápidas no meio da música para descansar a musculatura. Estas eram feitas sempre em partes estratégicas das cançóes (em finais de estrofes ou refrão, por exemplo) como uma espécie de convenção, não comprometendo o andamento e, muito menos, atrapalhando os cantores. Porém, era perceptível um "buraco sonoro" no momento em que não era executada, pois seu som é alto e quase não é composto por fragmentos de silêncio durante os toques.

É perceptível uma forma ímpar de comunicação com o sobrenatural quando o pandeiro começa a ser tocado, seja através da ativação de manifestaçôes corporais (sobretudo acompanhando corinhos de fogo) ${ }^{24} \mathrm{e}$ gritos, seja no convite a levar alegria ao culto. Seu uso torna o ritual democrático e aciona um formato de participação ativa do(a) crente, como é observado nos momentos de oportunidade ${ }^{25}$ ou em louvores mais efusivos. Todavia, vale ressaltar que qualquer pessoa que se sentir apta pode acessar o pandeiro, porém o pandeiro náo pode ser usado em todos os cultos.

Exemplificamos a performance nesses cultos pentecostais apresentando uma cena de execução de um corinho intitulado $O$ homem das mãos furadas (Composiçáo do grupo Irmãos Levitas). Ela começa com um senhor que, no momento da oportunidade, agradece a todos e pede para que fiquem de pé, afirmando: "quem estiver com dor de cabeça, ela vai embora agora". É ovacionado por palmas e gritos de glória e aleluia, pelo grande público presente (aproximadamente 50 pessoas) para o tamanho da igreja, que necessita colocar cadeiras na calçada para que todos(as) possam ficar acomodados. Esta fala sobre cura também tem

${ }^{24}$ Segundo De Paula (2016), os corinhos de fogo também são geradores de ação, e o pandeiro é o veículo que ajuda a impulsionar a corporeidade durante os cultos, além de caracterizar a peculiaridade popular, visível na condução das canções entoadas nos rituais. Sobre o tema ver Guerreiro, 2016.

${ }^{25}$ Momentos introdutórios do culto caracterizados pela presença de diversos membros que, de formas distintas, vão ao púlpito para fazer alguma homenagem a Deus perante a assembleia. 
ligação direta com a letra da música, que destaca diversos milagres ministrados pelo homem das mãos furadas (Jesus Cristo).

O pandeirista utilizava técnica bastante comum, "atacando" com a mão direita e balançando com a mão esquerda. Aparentemente isto gera certo desconforto e cansaço do instrumentista que gasta bastante energia, fato comprovado neste dia, o qual o pandeirista esvaía-se em suor mesmo numa noite fria de outono. Mesmo assim, isso não era motivo para que ele tocasse mais baixo. Ademais, ele não só esbanjava intensidade e naturalidade como cantava da mesma forma todos os hinos, demonstrando um grande conhecimento acerca do que estava desenvolvendo. Isso foi observado em muitos outros casos. Embora os improvisos nos toques sejam visíveis, eles náo ocorrem aleatoriamente, ou seja, são frutos de preparos adquiridos através da experiência dos músicos e de estudos prévios com o repertório. Destacamos ainda que o uso do pandeiro (embora não exclusivamente) tem o poder de promover maior polifonia no culto, já que aciona outros elementos sonoros ao ritual, tais como oraçóes, gritos e palmas.

\section{O SOM VIVO: O ATABAQUE NO CANDOMBLÉ KETU}

Era um sábado muito quente, na cidade de Seropédica, no estado do Rio de Janeiro. Naquele dia o terreiro, localizado em uma área rural da cidade, estava em festa. Após vários dias de rituais internos, chegara a hora do ápice: o ritual público, conhecido como ixirê ou xirê, ocorreria naquela noite. Este é entendido também como uma festa, uma comemoração entre participantes pelo fato dos rituais terem ocorrido dentro do esperado nos dias precedentes, e pela alegria de compartilhar a presença dos rrixá $^{26}{ }^{2}$ na terra distribuindo axé.

A poucas horas de se iniciar o xirê, os portóes do terreiro foram abertos. Pessoas da vizinhança e convidados dos(as) frequentadores(as) começaram a

${ }^{26}$ Divindades iorubás que representam as forças ou momentos da natureza.

Debates do NER, Porto Alegre, ANo 2I, N. 4O, P. 447-484, AGo./DeZ. 202 I 
chegar. Dentre o público, um homem ali era persona non grata: o antigo og $\tilde{a}^{27}$ da casa, que havia sido expulso do terreiro pelo seu comportamento, embora continuasse mantendo relaçôes amistosas com diversos(as) "filhos(as)-de-santo" da casa, fato que o permitiu ficar para acompanhar o xirê. Ao ser visto circulando pelo terreiro, o babalorixa $a^{28}$ chamou os ogãs daquele espaço e deu um alerta: "Não permitam que 'fulano' toque nos atabaques de maneira alguma!". A proibição se devia ao fato de não ser possível saber se o homem expulso havia passado pelos resguardos necessários para tocar os atabaques, como se abster de relaçóes sexuais no dia do ritual, não tomar bebidas alcoólicas e realizar um banho ritual de folhas.

Os atabaques, guardados em pé dentro de um quarto e cobertos com um pano branco, chamado de alá, foram retirados desde a manhá daquele dia e deixados do lado de fora, encostados em uma parede, para tomarem bastante sol. O objetivo era amolecer o couro para uma melhor afinação antes do xirê. O ogã expulso do terreiro demonstrava uma vontade de tocar o atabaque, porém os demais "filhos(as)-de-santo" estavam atentos para que isso não ocorresse. Entretanto, em um momento de descuido um estrondo foi ouvido. Os atabaques estavam caídos no chão. $\mathrm{O}$ espanto foi generalizado. Durante a distração dos ogãs da casa, o homem foi até os atabaques e, na tentativa de tocá-los, estes não se mantiveram em pé. Não foi possível levantá-los a tempo de disfarçar. Ele ficou extremamente constrangido, pois sabia o significado daquela queda. Por esse motivo, os ogâs da casa foram severamente repreendidos pelo babalorixá. $\mathrm{O}$ atabaque, tido como instrumento vivo pelos interlocutores (como explicaremos adiante), havia rejeitado o toque daquela pessoa. Nas semanas seguintes, foi necessário "dar comida”, ou seja, efetuar um determinado ritual para que o instrumento recuperasse novamente o seu axé.

27 Ogã é um cargo dado exclusivamente a homens que não manifestam o orixá e têm entre suas responsabilidades tocar o atabaque. As mulheres que são escolhidas pelo orixá e não o manifestam são chamadas de ekeji, mas estas náo tocam o atabaque no xirê.

${ }^{28}$ Fundador de uma casa de candomblé, também chamado de "pai-de-santo". 
A partir deste relato vivenciado em campo é possível analisarmos uma série de concepçóes do candomblé para entender como o atabaque - nosso foco de análise - atua como mídia, mobilizando sons, símbolos e corpos nesta relação. Primeiramente, vale ressaltar que o xirê é o momento no qual os orixás, vindos de um plano sobrenatural chamado de orun, se manifestam em seus(suas) "filhos(as)-de-santo" para dançar e distribuir seu axé aos(as) participantes. Esse é o único ritual do candomblé que permite a entrada do público de fora do terreiro. Durante o xirê, o elemento que envolve a todos(as) e torna o ritual possível é o repertório musical executado. Como todos os rituais do candomblé, sejam eles públicos ou privados, a sonoridade do xirêe um importante ponto de contato entre o mundo dos homens e o sobrenatural. É possível perceber na complexa sonoridade do xirê a polifonia que abrange essa paisagem sonora, visto que, somado ao som dos instrumentos e das cantigas em si, há os sons de manifestaçóes dos orixás vindos dos(as) "filhos(as)-de-santo"; saudaçóes dos membros ao orixá que chega; sons do público que responde às cantigas; e eventuais sons externos ao terreiro que também podem invadir o ambiente.

Em segundo lugar, destaca-se o termo axé, elemento central na religiáo dos orixás. Refere-se a um conceito complexo e muito debatido pelos pesquisadores. Bastide o considera "fundamento místico do candomblè", podendo significar uma série de elementos, como as "comidas oferecidas aos orixás [e] a energia das folhas colhidas para fazer o banho para os iniciados” (Bastide, 2001, p. 77), além de ser a energia primordial da vida, que pode ser tanto acumulável nas pessoas e nos objetos, quanto transmissível, sendo adquirida somente por "introjeção ou por contato", como aponta Santos (2012, p. 40).

Interlocutores do terreiro definem axé como tudo isso que foi descrito acima, mas com algo mais. Para eles(as), o axé, ali no terreiro, é uma força contida em todos os elementos utilizados no candomblé, sendo este o objetivo a ser alcançado. Esta força se realiza de várias maneiras, como através de rituais e do som contido nas palavras. Ao desejar boas coisas, integrantes do terreiro sempre reafirmam os votos dizendo “axé!". Nesse sentido, força, boa sorte, saúde, caminhos abertos, boas escolhas, vitórias e todos os desejos 
de prosperidade estão contidos no axé e na própria pronúncia desta palavra. Nessa perspectiva, o xirê é um ritual que permite a canalização desse axé trazido pelos orixás, redistribuindo-o aos(as) presentes. $\mathrm{O}$ atabaque é o meio pelo qual os orixás são convocados para transitarem de um plano sobrenatural a outro, o humano.

$\mathrm{O}$ instrumento que lidera o ritual público no candomblé é o atabaque, também chamado de ilú, acompanhado do agogô e xequerê, ${ }^{29}$ instrumentos que não abordaremos neste artigo. No terreiro sempre há três: o atabaque maior e mais grave, chamado de rum, o médio, rumpi, e o menor e mais agudo, lé. Eles sáo tocados com um tipo de baqueta chamada de aguidavi, as quais sáo geralmente confeccionadas com madeira de goiabeira, por ser resistente e flexível, podendo ser produzido também a partir de outras madeiras.

Os artefatos sonoros utilizados tanto no xirê quanto nas cerimônias internas do culto não são simples instrumentos musicais; eles se tornam entidades vivas, porque eles próprios têm a capacidade de dar vida, trazendo os orixás. Náo existe a menor possibilidade de comprar um instrumento em alguma loja, ou mesmo fabricá-lo, e imediatamente utilizá-lo em algum ritual. Todos eles devem receber axé a fim de serem vivificados, principalmente no caso dos atabaques, que passam por um processo de "nascimento" através de ritos específicos.

Inicialmente, os atabaques "comem", ou seja, recebem o sacrifício de animais somados a outros elementos para que ganhem vida. Assim como o ser humano que, ao nascer, recebe um orixá, responsável por cuidar dele durante toda a vida terrena, ao ser sacralizado o atabaque também recebe um orixá que será seu dono ou dona, um oboró (orixá masculino) ou uma iyabá (orixá feminino). É possível reconhecer que os atabaques passaram pelos rituais quando há um pano amarrado ao redor de cada um deles independente da ocasião, estejam guardados nos quartos ou em uso nas festas

${ }^{29}$ Cabe ressaltar que estes nomes eram os utilizados no terreiro etnografado para se referir a tais instrumentos. Em outros terreiros o xequerê também é conhecido por abê, e o agogô também pode ser conhecido como gâ, sendo que o mais comum é referir-se ao instrumento de uma campânula como gấ, e ao instrumento de duas campânulas como agogô.

Debates do NER, Porto Alegre, Ano 2 I, N. 40, P. 447-484, Ago./DeZ. 202 I 
públicas. Através da forma como se amarra este pano, é possível identificar se aquele atabaque específico tem como protetor um orixá masculino ou feminino. Se o formato do laço do pano for um "laçarote" (um tipo de laço borboleta), o atabaque pertence à uma iyabá; se for um "gravatá" (parecido com uma gravata), oboró. Mas é importante deixar claro que o atabaque, tendo como protetor um orixá masculino ou feminino, só pode ser tocado por homens durante o xirê, mas não qualquer homem: somente ogãs podem manipular e tocar nos atabaques.

$\mathrm{Na}$ maior parte do tempo, o pano amarrado ao redor do atabaque é da cor branca, mas pode acontecer de este pano ser da cor específica do orixá protetor do instrumento. No caso do terreiro analisado, o atabaque maior, o rum, foi amarrado nos dias de festa com um pano na cor marrom e com um laço "gravatá", indicando que seu orixá protetor é Xangô. O rumpi, atabaque médio, foi amarrado também com um laço "gravatá", com um pano na cor azul turquesa, indicando Oxóssi como seu protetor. E o atabaque menor, lé, levava um pano verde escuro amarrado também em laço "gravatá", cuja cor remete a Ogum.

Todos os outros instrumentos musicais do candomblé também passam por um processo de "nascimento", porém menos complexo do que o dos atabaques. Normalmente, devem ser sacralizados através de rituais que envolvem banhos de determinadas folhas e ervas. Para se produzir o axé, a força sagrada ou energia dos orixás, a presença do som através dos instrumentos é necessária na maioria dos rituais. Entretanto, para que esse som seja produzido também é necessário o axé (dos rituais), seja ele envolvendo sacrifícios animais ou o sumo de folhas e ervas, que estamos chamando aqui de sacralização. Um dos argumentos centrais deste trabalho é justamente a relação intrínseca entre estes dois elementos: é impossível pensarmos o som ou o axé dentro do candomblé ignorando a conexão entre eles. $\mathrm{O}$ axé precisa do som e o som precisa do axé.

O ogã, responsável pela execução musical nos rituais do candomblé, portanto, executante dos instrumentos citados, ocupa um dos cargos mais 
altos na hierarquia ${ }^{30}$ de um terreiro, cujo processo de formação se dá em três fases: ogâ apontado, suspenso e confirmado. A partir do momento em que uma pessoa passa a frequentar um terreiro de candomblé, ela é um abiá, um noviço na religiáo que ainda não passou por nenhum ritual iniciático. Se um orixá, manifestado em um(a) "filho(a)-de-santo", escolhe um homem para servi-lo, este homem torna-se um ogã apontado. Há, então, uma cerimônia em que outros ogâs levantam o ogã apontado, seja em seus braços ou em uma cadeira, levando-o a certos lugares sagrados do terreiro, como se estivessem apresentando-o aos orixás, à casa e à comunidade, quando todos(as) os(as) membros(as) do terreiro vêm tomar-lhe a bênção. Assim, ele se torna um ogâ suspenso.

Após passar efetivamente pelo ritual iniciático, ele se torna um ogã confirmado, com cargo hierárquico abaixo somente do "pai" ou "mãe-de-santo", e com todos os direitos e deveres que a função lhe impóe. Um destes direitos é o de aprender a entoar as cantigas sagradas e tocar os instrumentos utilizados durante o xirê.

Em fase posterior, o babalorixá pode conceder ao ogã um título honorífico em alguma área em que este se destaque. Dessa maneira, conforme nossos interlocutores, ele pode se tornar um pejigan (um ogã responsável pelos peji, quartos dos orixás), axogum (ogã responsável pelo sacrifício dos animais) ou um alabê (ogã responsável por conduzir as cantigas para os orixás durante o ritual público), entre outras funçóes. Isto não significa que um alabê não possa sacrificar um animal ou um axogum não esteja autorizado a cantar num xirê, mas o recebimento de um título honorífico torna aquele ogã uma referência naquela determinada atividade. É possível, também, que um babalorixá crie alguns títulos que passam a existir somente em seu terreiro a fim de administrar egos e evitar conflitos entre os(as) participantes.

${ }^{30}$ A hierarquia no candomblé já foi extensamente descrita por diversos autores, dentre eles destaco Vivaldo da Costa Lima (2003). Dentro do terreiro, a hierarquia é realizada de acordo com os cargos ocupados, cuja atribuição se dá, sobretudo, de acordo com a senioridade do postulante. A figura do "mais velho(a)" é sempre reverenciada no candomblé por estar em posição hierárquica superior, revelando, assim, uma estrutura gerontocrática da religião. Sobre esse debate, ver Eugênio (2017). 
Apesar de não haver uma hierarquia formal entre os ogãs, normalmente o alabê com maior prestígio dentro do terreiro é o responsável pela condução das cantigas e pelo toque do rum, o atabaque maior. Boa memória e um mínimo conhecimento da língua litúrgica (iorubá), além da habilidade em tocar o atabaque, são requisitos esperados de um alabê. Não é possível falarmos de um período exato de duração para uma aprendizagem mínima das cantigas por um ogã recém-confirmado. Este é um processo que leva anos, e depende, também, da familiaridade do ogã com o universo do candomblé, visto que alguns podem ter crescido dentro do terreiro, enquanto outros iniciam sua jornada religiosa já na vida adulta.

A primeira dificuldade que um ogã vai encontrar para aprender as cantigas é o idioma. Elas são entoadas em iorubá, em sua forma arcaica, diferente do iorubá moderno. Segundo Angela Lühning:

A parte das letras - cantadas no iorubá arcaico - representa, ainda, um certo problema: ninguém dos iniciados fala correntemente o ioruba. Trata-se de uma língua meramente litúrgica que se traduz através de certas palavras chaves que fazem parte de um vocabulário básico. O conteúdo geral se sabe por causa dos movimentos e gestos da dança que visualizam as letras das cantigas. Porém, precisa-se de muito tempo e muita dedicação por parte da iaô (vide nota 12) para aprender estas traduçóes codificadas. Infelizmente o número das pessoas que conhecem o conteúdo e o significado das letras e das danças diminui constantemente (Lühning, 1990, p. 118).

A boa memória, qualidade muito elogiada dentro de um terreiro de candomblé, sempre foi de fundamental importância em uma religião cuja transmissão se dá por via oral. O conhecimento das cantigas entre os ogãs também se dá da mesma forma. Um tabu neste processo de conhecimento é o chamado "caderno de fundamento". Nele, não só os ogãs anotam cantigas, mas, também, "pais" e "mães-de-santo" anotam segredos e histórias para não se perderem com o tempo. A adoção desse recurso dentro dos terreiros tem um caráter auxiliar, sendo a transmissão oral e a vivência cúltica as principais vias de aprendizagem. O tabu se dá justamente por este caráter 
ambíguo: todos(as) lançam mão desse recurso, mas poucos admitem entre si, para demonstrar sua boa memória. Sobre a relação entre ogã e atabaque, Amaral e Silva nos dão uma interessante descrição:

[...] Cada um executa uma frase rítmica individualmente, perfazendo, no conjunto, um polirritmo, cuja marcação é dada pelo Rum, responsável, ao mesmo tempo, pelo "repique" ou "dobrado" (floreio), que dáo à música um caráter diferencial acentuado conforme os ritmos de cada orixá. Essa função particular do Rum estabelece sua maior importância em relação aos outros dois atabaques. A expressão "dar o rum no orixá" é indicativa da posição desse instrumento no conjunto da "orquestra". Essa mesma importância é observável por ocasião da reverência obrigatória aos atabaques, quando o Rum é o primeiro a ser saudado pelos fiéis, também cabendo a ele noticiar e saudar a chegada de visitantes ilustres ao terreiro (receber o "dobrar dos couros" é sinal de grande prestígio). Portanto, cabe ao chefe dos alabês a responsabilidade pelo Rum particularmente e também pelos outros atabaques; não só durante o toque, mas por sua manutenção permanente. Quando não estão em uso, os atabaques devem ser cobertos por um pano branco e, uma vez que são considerados como portadores de axé, eles não podem ser removidos do terreiro. Pelo mesmo motivo, são tratados com especial reverência quando, por algum acidente, caem ao chão. (Amaral, Silva, 2009, p. 7)

Um atabaque deve sempre estar em pé, apoiado no pepelê, base de madeira que o sustenta. Um atabaque vir ao chão é sinal de mau agouro, pois se ele é vivo e traz vida através de seu som, deitá-lo significa a diminuição de sua força vital. O espanto causado pela queda dos atabaques no relato com o qual iniciamos esta análise se deve a esse motivo. Segundo interlocutores, o atabaque veio ao chão como um tipo de recusa pelo toque do homem expulso do terreiro. Teoricamente, ele estava habilitado a tocar o atabaque por ser homem e ter passado pelos preceitos ${ }^{31}$ para se tornar ogã. Porém, ainda segundo os(as) "filhos(as)-de-santo", a recusa do

31 Obrigaçôes rituais, que incluem não somente as realizadas dentro dos limites do terreiro, mas também o período de resguardo que se segue à iniciação (se o indivíduo manifesta

Debates do NER, Porto Alegre, ano 2 I, N. 40, P. 447-484, Ago./DeZ. 202 I 
atabaque ao toque se deu pelo fato do corpo do ogá estar "sujo", ou seja, não havia passado pelos resguardos necessários.

Tal acusação sobre o corpo "sujo" e, por isso, a impossibilidade da pessoa se relacionar com o sagrado, é emblemática para mostrar a importância da corporeidade nesse ambiente religioso. No que tange ao escopo deste artigo, o sobrenatural se manifesta nos corpos dos(as) "filhos(as)-de-santo" através do som dos atabaques no ritual público. Se, por um lado, os ogãs têm o domínio exclusivo dos atabaques, por outro, o campo da dança e da manifestação dos orixás nos corpos não são áreas nas quais o ogã pode atuar. O xirê é uma complementação de papéis desempenhados naquele âmbito. $\mathrm{O}$ ogá toca as cantigas numa ordem pré-determinada e, ao ouvir a cantiga que o convoca, o orixá se manifesta no corpo do(a) "filho(as)-de-santo". E é esse corpo, carregando dentro de si o orixá, que vai dançar entre os seres humanos e distribuir a todos os presentes na cerimônia o axé trazido de um plano sobrenatural.

O modo de dançar do orixá também é pré-determinado. Muitas vezes a cantiga relata histórias ou características do orixá, ao que ele responde corporalmente, com o movimento de seu corpo correspondendo ao que está sendo cantando. Por exemplo, ao se cantar para Ogum, orixá guerreiro, nas cantigas em que sua bravura é exaltada o orixá dança fazendo movimentos com os braços como se estivesse cortando as cabeças dos inimigos. Oxóssi, orixá caçador, dança muitas vezes simulando com suas mãos o atirar de uma flecha. Mas não é somente o orixá manifestado no corpo de seu(sua) "filhos(as)-de-santo" que dança. Os membros do terreiro que podem fazer parte da "roda" do xirê, ou seja, aqueles que podem dançar ao som dos atabaques, dançam de acordo com as características do orixá que está sendo louvado pelas cantigas dos ogãs. Podemos tomar como exemplo a orixá feminina $O b a ́$, que é relembrada através de um mito no qual ela é enganada por Oxum, e levada a cortar a própria orelha. A dança de Obá é

o orixá) ou confirmação (se a pessoa for um ogã ou uma ekeji). O período tanto da iniciação/confirmação quanto do resguardo varia de acordo com o orixá de cada pessoa.

Debates do NER, Porto Alegre, ANo 2I, N. 4O, P. 447-484, Ago./DeZ. 202 I 
lenta e faz-nos lembrar da dor por ela sofrida, em um movimento corporal no qual os(as) "filhos(as)-de-santo" levam uma de suas mãos à altura da orelha como se estivessem tampando-a.

É exatamente pelo fato de o instrumento ser portador de axée, portanto, estar "vivo", que a mecanização (eletrificação) do áudio não pode levar um(a) "filho(a)-de-santo" ao transe. Durante o trabalho de campo, alguns membros do terreiro foram questionados sobre possíveis sensaçôes relacionadas aos sons mecanizados, isto é, se ao ouvirem alguma cantiga gravada eles sentiam alguma coisa. Alguns deles disseram que sentiam a mesma alegria, emoção, ou seja, os sentimentos que aquelas cantigas traziam para eles. Entretanto, também disseram que a audição das cantigas gravadas não seria suficiente para a manifestação de um orixá. A partir das observaçóes feitas durante o trabalho de campo e das conversas informais, é possível sugerir um fator que impede a manifestação do orixá no(a) "filho(a)-de-santo" que ouve uma cantiga gravada.

Em certo sentido, as concepções dos interlocutores vão ao encontro de um conceito apresentado por Schafer (2011b), no qual o autor chama a atenção para a separação entre o som e o seu emissor, classificando esse fenômeno como "esquizofonia"32. O som deve, necessariamente, emanar diretamente de seu emissor para que haja a manifestação do orixá. Mais do que uma resistência a uma certa "modernização" do candomblé, a não-manifestação pela audição de cantigas por meio de gravaçóes deixa claro que o ambiente (tanto sonoro quanto em outros aspectos) é fundamental para que a manifestação do orixá ocorra. Estar no terreiro significa um contato direto com a energia dos orixás, através da indumentária, dos fios-de-conta, do banho de folhas, em resumo, de toda a parafernália material e simbólica

32 "Desde a invenção dos equipamentos eletrônicos de transmissão e estocagem de sons, qualquer som natural, não importa quão pequeno seja, pode ser expedido e propagado ao redor do mundo, ou empacotado em fita ou disco, para as geraçóes do futuro. Separamos o som da fonte que o produz. A essa dissociaçáo é que chamo esquizofonia [...]" (Schafer, 2011b, p. 160). 
portadora de axé. Por mais tecnológicos que sejam nossos meios de captação e gravação de som, eles não conseguiriam ser idênticos ao som natural (e, do ponto de vista cosmológico, não seria um meio de transmissão de axé). Ou seja, a dissociação entre o som mecânico e o som natural, a separação entre o som e o instrumento portador de axé, não possibilita a manifestação do orixá, pois o som sem o axé se torna apenas mero ruído.

\section{REFLEXÓES FINAIS}

Embora os três contextos religiosos descritos neste artigo estejam localizados em áreas geograficamente periféricas, a noção de periferia, que trabalhamos a partir do conceito de Ginzburg, diz respeito, sobretudo, ao sentido cultural. Esse espaço periférico, pensado através da chave da cultura, se situa em uma zona de clivagem, o que permite uma maior troca, experimentaçáo, sobreposição e adaptação nas práticas dessas comunidades religiosas. Há uma tensão intra-religiosa entre as comunidades situadas dentro de um espaço periférico e aquelas que se consideram mais globalizadas. Desse modo, as primeiras se afastariam de uma homogeneização (padronização) acústica justamente porque agregam outros elementos musicais a convençóes pré-estabelecidas, se diferenciando do que é produzido em contextos hegemônicos.

Conforme a exposição dos três campos, constatamos que a produção acústica exibiu significados distintos e alguns temas configuraram-se transversais às estruturas religiosas estudadas, como processos de aprendizagem, construção de hierarquias, mecanização do som e impulso à corporeidade. Como sinalizamos na introdução, embora estejamos abordando contextos espaciais bastante distintos, tratam-se de práticas religiosas que podem ser consideradas periféricas, segundo a ideia de Ginzburg (1986). Neste sentido, consideramos estes movimentos como periféricos, não em sentido estritamente geográfico, mas pela forma como suas práticas são vistas por outros segmentos do campo religioso e social.

Nesta perspectiva, um mesmo instrumento pode ser operado de diferentes formas, a depender do contexto e da experiência da pessoa que o 
executa. Chamamos este aprendizado de vivência cúltica, já que ocorre no cotidiano da religiáo e, principalmente, no momento ritual. A aprendizagem segue caminho semelhante e, dentre as observadas, as mais comuns fazem uso da transmissão por códigos orais e visuais e, em menor escala, pela via escrita. Esse modo abre espaço para que improvisos ocorram durante a execução, garantindo, em certa medida, autonomia por parte de quem toca. Todavia, esse processo só é possível a agentes que recebem permissão para realizar tal performance. Esta tem relação com as hierarquias presentes em cada uma das práticas religiosas observadas e com os modos de acesso ao sobrenatural por meio de mediaçóes materiais, tanto no que concerne aos objetivos de alcançar efeitos positivos, como para combater ou controlar outras forças sobrenaturais.

No candomblé da nação ketu, apenas homens têm autorização para exercer essa função durante o xirê. Logo, conhecer a técnica não é suficiente, já que várias etapas preparatórias e confirmatórias compóem esse procedimento. Além disso, a partir do momento em que o instrumento ganha vida, seu uso é restrito a determinada casa.

Diferentemente, os outros dois contextos podem ser considerados mais flexíveis, mas isso não impede seu percurso pelo crivo de alguma autoridade. Ao possibilitar condiçóes de participação, independentemente do gênero e da faixa etária, tanto os cultos pentecostais quanto os rituais Zione ainda permitem a participação ativa de fiéis. Como o instrumento não é consagrado formalmente, embora em algumas comunidades possa haver uma bênção ou algo semelhante, sua valorização acaba sendo relativizada de acordo com a necessidade no culto. Com efeito, tanto para os Zione quanto para os pentecostais, os instrumentos são fundamentais para a condução dos rituais. Entretanto, a partir do momento em que outras mídias são incorporadas, a situação modifica-se, emergindo conflitos concernentes à legitimidade e à eficácia de artefatos sonoros para a produção de sensaçóes e poderes espirituais.

Ao passo que certos templos são ampliados em tamanho (na estrutura física e em número de fiéis), demandando a adoção de instrumentos 
eletrificados, o pandeiro fica relegado a uma posição de "reserva”, mas não sai de cena. No pentecostalismo, uma guitarra, bateria ou teclado improvavelmente competirá com um pandeiro, já que poderão dialogar, mas não estarão em pé de igualdade. Já o xigubo dificilmente conversa com o "piano", e a relação vai além do fator timbre, pois também leva em consideração o entendimento do líder da casa. Já no candomblé, a hierarquização se dá entre pessoas, porém também há pequenas gradaçôes entre os usos dos três diferentes tipos de atabaque, que são reverenciados por possuírem vida e terem protagonismo na cerimônia pública.

As habilidades desenvolvidas através de um objeto sonoro podem ser adquiridas por meio de fontes oriundas da expansão tecnológica, como internet, por exemplo. Isso faz com que as novas geraçóes ou os(as) íntimos(as) das novidades se relacionem de modo distinto com o instrumento musical, enaltecendo disparidades entre os pares e/ou modificando - mesmo que em escala micro - o andamento do ritual. Outro aspecto tem a ver com a eletrificação da fonte sonora, e como esta pode ou não estabelecer vínculos com os instrumentos acústicos comentados. No caso do pandeiro, a relação é pacífica, à primeira vista, mas faz emergir opinióes desfavoráveis (em especial dos não executantes) à junção do pandeiro com artefatos eletrificados. Mesmo em momentos que podem levar ao transe, playback e pandeiro atuam juntos, não prejudicando o andamento da atuação do Espírito Santo nas pessoas presentes no culto.

De modo distinto, dentro do terreiro etnografado ele pode interferir diretamente na ação do orixá, fato que torna essa religiosidade interpretada como a-mecanizada. Entre os Zione, a mecanização do som não é necessariamente um problema. Do contrário, pianos, microfones e caixas de som são bem-vindos e, muitas vezes, percebidos como sinônimo de modernidade, embora alguns profetas afirmem que precisam do som do xigubo para acessar o sobrenatural.

Eletrificada ou não, a fonte sonora pode causar interferência direta no contato com o sobrenatural, seja através da manifestação corporal ou 
da possibilidade de gerar distintas formas de curas. No pentecostalismo, movimentar o corpo, gritar, chorar e desmaiar são açóes que ocorrem corriqueiramente em certos momentos do culto e a música, normalmente, age como pano de fundo. Nesse sentido, o toque do pandeiro, em especial nos corinhos de fogo, auxilia para "acender a chama" do crente, enaltecendo o estado de vibraçáo e de transe dos(as) participantes. Posteriormente, a ação do Espírito pode proporcionar um estado de paz ou mesmo conceder o reestabelecimento de alguma enfermidade física ou psíquica.

Através da diliza, os Ziones também estimulam sensaçôes semelhantes. Como esta dança integra o roteiro ritual, ela necessita diretamente do toque do xigubo para acontecer. Do mesmo modo, o candomblé depende dos atabaques no xirê para que o axé desses, recebidos através do seu ritual de sacralização, possa induzir o(a) "filho(a)-de-santo" à manifestação do orixá, que, por sua vez, usa o seu corpo como mídia para a distribuição dessa energia entre os presentes, conectando a audiência do ritual com o sobrenatural. Nesse culto afro-brasileiro, a dança náo é apenas uma resposta a estímulos sonoros, ao acaso, assim como também não é nos dois contextos pesquisados, mas uma constante que, inclusive, segue padróes de acordo com quem se manifesta. Desse modo, verificamos que os diferentes sons desses instrumentos, são capazes de acionar determinado tipo de corporeidade já padronizado, com pequenas nuances perceptíveis a insiders, que, inclusive, podem ser semelhantes entre os campos.

A partir dessa breve análise, observamos que a relação com o sobrenatural em um contexto periférico necessita direta ou indiretamente destes artefatos sonoros, permitindo relacionar certas práticas religiosas às sonoridades de determinados instrumentos. Em outros termos, tais práticas também podem ser caracterizadas pelos sons que elas produzem. Assim, partir do ponto de vista do instrumento pode ser fundamental para a compreensão de outros aspectos rituais e comportamentais das práticas religiosas e pode oferecer pistas a respeito de mudanças estéticas e das maneiras de diálogo entre os seres humanos e o sobrenatural mediadas pela música. 


\section{REFERÊNCIAS}

ALBUQUERQUE JUNIOR, Valdevino. “Exalte e receba!”: A expressão mítico-ritual dos corinhos de fogo no culto [neo]pentecostal. 2014. Dissertação (Mestrado em Ciência da Religião) - PPGCR/UFJF, Juiz de Fora, 2014.

AMARAL, Rita; SILVA, Vagner Gonçalves da. Cantar para subir - um estudo antropológico da música ritual no candomblé paulista. $N A U-$ Núcleo de Antropologia Urbana da USP, São Paulo, 2009. Disponível em <http:// www.n-a-u.org/Amaral\&Silva1.html>. Acesso em: 29 abr. 2018.

ARAÚJO, Samuel. Acoustic Labor in the Timing of Everyday Life; A Historical-Ethnographic Approach to Samba in Rio de Janeiro (1917-1988). 1992. Ph.D. (Dissertation Musicology Division) - School of Music, University of Illinois at Urbana-Champaign, Illinois, 1992.

BASTIDE, Roger. O Candomblé da Bahia: rito nagô. São Paulo: Companhia das Letras, 2001.

BOURDIEU, Pierre. A economia das trocas simbólicas. São Paulo: Perspectiva, 2009.

CAVALLO, Giulia. Curar o passado: mulheres, espíritos e "caminhos fechados" nas igrejas Zione em Maputo, Moçambique. 2013. Tese (Doutorado em Antropologia) - Instituto de Ciências Sociais, Universidade de Lisboa, Lisboa, 2013.

COMAROFF, Jean. Body of Power, Spirit of Resistance. The Culture and History of a South African People, Chicago: University of Chicago Press, 1985. CUNHA, Magali do Nascimento. A explosáo gospel: Um olhar das ciências humanas sobre o cenário evangélico no Brasil. Rio de Janeiro: Mauad X, 2007.

DE PAULA, Robson Rodrigues. "Sinta este fogo irmão": cosmologia pentecostal, noção de pessoa e "corinhos de fogo". Tempo da Ciência, Toledo, v. 23. n. 45, p. 53-64, jan./jun. 2016.

EUGÊNIO, Rodney William. A bênção aos mais velhos: poder e senioridade nos terreiros de Candomblé. Mairiporã: Arole Cultural, 2017. 
FERREIRA, Sonia; TRAVANCAS, Isabel. Antropologia da mídia: um campo em construção no Brasil e em Portugal. Revista Famecos, Porto Alegre, v. 21, n. 2, 2014.

FRY, Peter. O Espírito Santo contra o Feitiço e os espíritos revoltados: "civilização" e "tradição" em Moçambique. Mana, Rio de Janeiro, v. 6, n.2, p. 65-95, oct. 2000.

GINZBURG, Carlo. O queijo e os vermes: o cotidiano e as ideias de um moleiro perseguido pela inquisição. São Paulo: Companhia das Letras, 1986. GUERREIRO, Clayton. A gira do "reteté": Uma análise das disputas sobre o "pentecostalismo legítimo”. 2016. Dissertação (Mestrado em Ciências Sociais) - Universidade Federal de São Paulo, Escola de Filosofia, Letras e Ciências Humanas, Guarulhos, São Paulo, 2016.

HONWANA, Alcinda. Espiritos Vivos, Tradiçôes Modernas: Possessão de Espíritos e Reintegração Social Pós-Guerra no Sul de Moçambique. Lisboa: Promédia, 2002. KRAUSE, Bernie. A grande orquestra da natureza: descobrindo as origens da música no mundo selvagem. 1. ed. Rio de Janeiro: Zahar, 2013.

LIMA, Vivaldo da Costa. A família de santo nos candomblés jejes-nagôs da Bahia: um estudo de relaçóes intragrupais. Salvador: Corrupio, 2003.

LOPES, Artur Costa. A música como instrumento para o diálogo inter-religioso. 2016. Dissertação (Mestrado em Música) - Universidade Federal do Rio de Janeiro. Rio de Janeiro, 2016.

LÜHNING, Angela. Música: coração do candomblé. Revista USP, n. 7 , p. 115-124, 1990.

MENEZES BASTOS. Rafael José. Audição do Mundo Apùap II Conversando com "Animais", "Espíritos” e outros Seres. Ouvindo o Aparentemente Inaudível. Antropologia em primeira mão: UFSC, 2013.

MEYER, Birgit. Mediação e Imediatismo: formas sensoriais, ideologias semióticas e a questão do meio. Campos, Paraná, v. 16, n. 2, p.145-164, 2015. ORO, Ari Pedro. O neopentecostalismo macumbeiro. Revista USP, São Paulo, n. 68, p. 319-332, 2006. 
ORSI, Robert. Material children. Making God's presence real through Catholic boys and girls. In: LYNCH, G.; MITCHELL J. (org.). Religion, media and culture: A reader. New York: Routledge, p. 147-158, 2012.

OLIVEIRA, Samuel. Heterogeneidades no choro: um estudo etnomusicológico. 2003. Dissertação (Mestrado em Música) - UFRJ/EM, Rio de Janeiro, 2003.

PASSADOR, Luiz Henrique. Guerrear, casar, pacificar, curar: o universo da "tradiçáo" e a experiência como HIV/Aids no Distrito de Homoíne, Sul de Moçambique. 2011. Tese (Doutorado em Antropologia Social) - IFCH, Unicamp, Campinas, 2011. PEREIRA, Réia Sílvia Gonçalves. "Deixa o menino rodar": O carisma reteté em uma igreja pentecostal da periferia. Debates do NER, ano 19, n. 36, p. 267-305, 2019.

SANTOS, Juana Elbein dos. Os Nàgô e a morte: Pàde, Àsèsè e o culto Égun na Bahia. 14. ed. Petrópolis: Vozes, 2012.

SANTOS, Lívia Reis. Ser Universal: crentes engajados e práticas cotidianas na cidade de Maputo. 2018. Tese (Doutorado em Ciências Sociais) - Instituto de Ciências Sociais, Universidade do Estado do Rio de Janeiro - UERJ, Rio de Janeiro, 2018.

SCHAFER, R. Murray. A afinação do mundo: uma exploração pioneira pela história passada e pelo atual estado do mais negligenciado aspecto do nosso ambiente: a paisagem sonora. 2.ed. São Paulo: Ed. Unesp, 2011 a.

SCHAFER, R. Murray. O Ouvido Pensante. 2.ed. São Paulo: Ed. Unesp, 2011 b. STOLOW, Jeremy. Religião e Mídia: notas sobre pesquisas e direçoes futuras para um estudo interdisciplinar. Religiäo \& Sociedade, v. 34, n. 2, Rio de Janeiro, jul/dez 2014.

ZAMPARONI, Valdemir Donizette. Entre Narros \& Mulungos (1890-1940). 1998. Tese (Doutorado em História Social) - FFLCH/USP, São Paulo, 1998.

Recebido em: 02/09/2021

Aprovado em: 24/11/2021 
ENSAIO VISUAL 